\title{
Nitrogen concentration in dry matter of the fifth leaf during growth of greenhouse tomato plants
}

\author{
Jorge E. Rattin ${ }^{1}$; Jerônimo L. Andriolo ${ }^{2}$; Márcio Witter ${ }^{2}$ \\ ${ }^{1}$ Universidad Nacional de Mar del Plata. RN 226, km 73,5. Balcarce, Pcia. de Buenos Aires, Argentina; ${ }^{2}$ UFSM, 97.105-900 Santa \\ Maria-RS. E-mail: andriolo@creta.ccr.ufsm.br.
}

\begin{abstract}
The nitrogen concentration in dry matter of the fifth leaf during growth of a greenhouse tomato crop was determined. Plants of hybrid Monte Carlo were grown in $4.5 \mathrm{~L}$ bags, using a commercial substrate, in a plant density of 3.3 plants $\mathrm{m}^{-2}$. A nutrient solution containing, in mmol L-1: $\mathrm{KNO}_{3}, 4.0 ; \mathrm{K}_{2} \mathrm{SO}_{4}, 0.9 ; \mathrm{Ca}\left(\mathrm{NO}_{3}\right)_{2}, 3.75 ; \mathrm{KH}_{2} \mathrm{PO}_{4}, 1.5$; $\mathrm{MgSO}_{4}, 1.0$; iron chelate $19.10^{-3}$, was used as reference. Microelements were added by a commercial mixture. The T3 treatment was equal to the reference nutrient solution, whereas in treatments T1, T2, T4 and T5 quantities of all nutrients from T3 were multiplied by $0.25,0.50,1.25$ and 1.50 , respectively. In each treatment, the volume of $1 \mathrm{~L}$ of nutrient solution was supplied to each plant once a week by fertigation. Periodically destructive measurements were made from anthesis to ripening of the first truss, to determine dry matter and $\mathrm{N}$ concentration in shoot and in fifth leaf tissues, counted from the apex to the bottom of the plant. Five dilution curves were fitted from data of $\mathrm{N}$ concentration in the fifth leaf and shoot dry matter accumulation during growth of plants. A general relationship was adjusted between actual $\mathrm{N}$ concentration in shoot $(\mathrm{Nt})$ and in the fifth leaf $(\mathrm{Nf}): \mathrm{Nt}=1.287 \mathrm{Nf}\left(\mathrm{R}^{2}=0.80\right)$. This relationship could be used to estimate the $\mathrm{N}$ status of plants by means of a nitrogen nutrition index (NNI), from analysis of the fifth leaf sap.
\end{abstract}

Keywords: Lycopersicon esculentum, nutrients, mineral nutrition, fertilization.

\section{RESUMO}

Concentração de nitrogênio na matéria seca da quinta folha no decorrer do crescimento de plantas de tomateiro em estufa

Determinou-se a concentração de nitrogênio na massa seca da quinta folha definitiva no decorrer do crescimento de uma cultura de tomateiro. Plantas do híbrido Monte Carlo foram cultivadas em sacolas plásticas contendo $4,5 \mathrm{~L}$ de um substrato comercial, na densidade de 3,3 plantas $\mathrm{m}^{-2}$. Foi empregada como referência uma solução nutritiva contendo, em mmol L-1: $\mathrm{KNO}_{3}, 4,0 ; \mathrm{K}_{2} \mathrm{SO}_{4}, 0,9$; $\mathrm{Ca}\left(\mathrm{NO}_{3}\right)_{2}, 3,75 ; \mathrm{KH}_{2} \mathrm{PO}_{4}, 1,5 ; \mathrm{MgSO}_{4}, 1,0$; quelato de ferro $19.10^{-3}$. Os demais micronutrientes foram fornecidos através de uma solução completa. $\mathrm{O}$ tratamento $\mathrm{T} 3$ foi igual à dose de referência e os demais tratamentos foram fixados em doses múltiplas de T3, multiplicando-se as quantidades de todos os nutrientes por 0,$25 ; 0,50$; 1,25 e 1,50, para os tratamentos T1, T2, T4 e T5, respectivamente. Em cada tratamento, o volume de $1 \mathrm{~L}$ de solução foi aplicado para cada planta em intervalos semanais, por fertirrigação. Medidas periódicas foram feitas no período entre a antese e a maturação dos frutos da primeira inflorescência, para determinar a acumulação de massa de matéria seca e de $\mathrm{N}$ na parte aérea e na quinta folha, contada do ápice para a base da planta. Cinco curvas de diluição foram ajustadas com dados de concentração de $\mathrm{N}$ na quinta folha e de acumulação da massa seca no decorrer do crescimento das plantas. Uma relação foi ajustada entre a concentração de $\mathrm{N}$ na parte aérea da planta $(\mathrm{Nt})$ e na quinta folha $(\mathrm{Nf}): \mathrm{Nt}=1.287 \mathrm{Nf}\left(\mathrm{R}^{2}=0.80\right)$. Essa relação poderá ser empregada para avaliar o estado nutricional das plantas, empregando-se o índice de nutrição de nitrogênio (NNI), a partir de dados de análise dos tecidos da quinta folha.

Palavras-chave: Lycopersicon esculentum, nutrientes, nutrição mineral, adubação.

(Recebido para publicação em 22 de agosto de 2001 e aceito em 11 de junho de 2002)

$\mathrm{T}$ omato is the most important greenhouse vegetable crop in many countries. Cultivation is done in soil and also in soilless culture, and fruit yield can reach $15-18 \mathrm{~kg} \mathrm{~m}^{-2}$ at the end of a growing cycle of about 270 days (Castilla, 1995; Martinez, 1995). When plants are grown in soil, growers tend to overestimate mineral requirements of the crop, and the risk of salinity becomes a problem of concern. In soilless culture using substrates, nutrients are supplied to plants by means of a nutrient solution and volumes are delivered from estimates of diurnal transpiration fluxes (CTIFL, 1995). Non-absorbed nutrients run-off and are discharged into the soil, leading to cultural and environmental problems.

Models have been suggested to adjust the offer to the demand of nutrients for several crops, based mainly in relations between plant nutrient concentration and growth (Ulrich, 1952); Burns, 1992; Lemaire \& Denoix, 1987; Grindlay et al., 1993; Lemaire et al., 1997; Greenwood et al., 1990, 1991; Greenwood \& Stone, 1998; Rahn, 1997; Robinson, 1997; Le Bot et al., 1997; Colnenne et al., 1998). For nitrogen, Caloin \& Yu (1984) and Hardwick (1987) described the dynamics of plant growth as a consequence of the functional equilibrium between growth of a vegetative and a structural compartment. The critical N concentration in the plant at any stage during its ontogeny was defined as the minimum plant $\mathrm{N} \%$ necessary to achieve the maximum growth rate of the crop, and was represented by a power equation as follows (Lemaire et al., 1997; Justes et al., 1997):

$$
\mathbf{N} \%=\mathbf{a}(W)^{-b}
$$

where coefficient $a$ represents the plant $\mathrm{N} \%$ at early stages of development, coefficient $b$ the decline 
in critical plant $\mathrm{N} \%$ during growth (the slope of the curve) and $W$ the aboveground biomass of the crop (Salette \& Lemaire, 1987).

The critical $\mathrm{N}$ dilution curve could be used to estimate the $\mathrm{N}$ status of the plant at any stage of plant growth period, by means of a nitrogen nutrition index (NNI), as follows (Lemaire et al., 1997):

$$
\mathbf{N N I}=\mathbf{N t} / \mathbf{N c}
$$

where $N t$ is the actual shoot $\mathrm{N}$ concentration and $N c$ the critical $\mathrm{N}$ concentration for the same accumulated biomass.

Estimates of shoot $N t$ by destructive measurements using dry matter of whole shoot organs are difficult to accomplish. For the tomato crop, the use of the fourth (Lopez \& Marotta, 1998) or the fifth leaf (Caron \& Parent, 1989), counted from the apex to the bottom of the plant has been preconized, as being representative of the whole plant. Nevertheless, strong fluctuations of $\mathrm{N}$ concentration among shoot organs and also among leaves were observed during the ontogeny of the plant, values being higher at younger stages of plant development (Andriolo, 1995). The validity of the fifth leaf as an indicator of the actual $\mathrm{N}$ shoot concentration at any stage of plant growth has not yet been demonstrated.

The aim of this work was i) to determine the $\mathrm{N}$ concentration in the fifth leaf during growth of tomato plants supplied with five levels of $\mathrm{N}$ nutrition and ii) to search for a general relationship between $\mathrm{N}$ concentration in the fifth leaf and in the shoot.

\section{MATERIAL AND METHODS}

The experiment was carried out at the Universidade Federal de Santa Maria, Rio Grande do Sul State, South Brazil (latitude: $29^{\circ} 43^{\prime} \mathrm{S}$, longitude: 53²' 'W, altitude: 95m), in spring 1999. Seeds of beef steak hybrid Monte Carlo were sown on $9^{\text {th }}$ July, and at the stage of six leaves they were transferred to a polyethylene greenhouse (10 $\mathrm{m}$ wide, 20 $\mathrm{m}$ length and 4,5 $\mathrm{m}$ height), where they were grown in individual $4.5 \mathrm{~L}$ bags, using a commercial substrate (Plantmax ${ }^{\circledR}$ ). Bags were placed inside gullies at a plant density of 3.3 plants

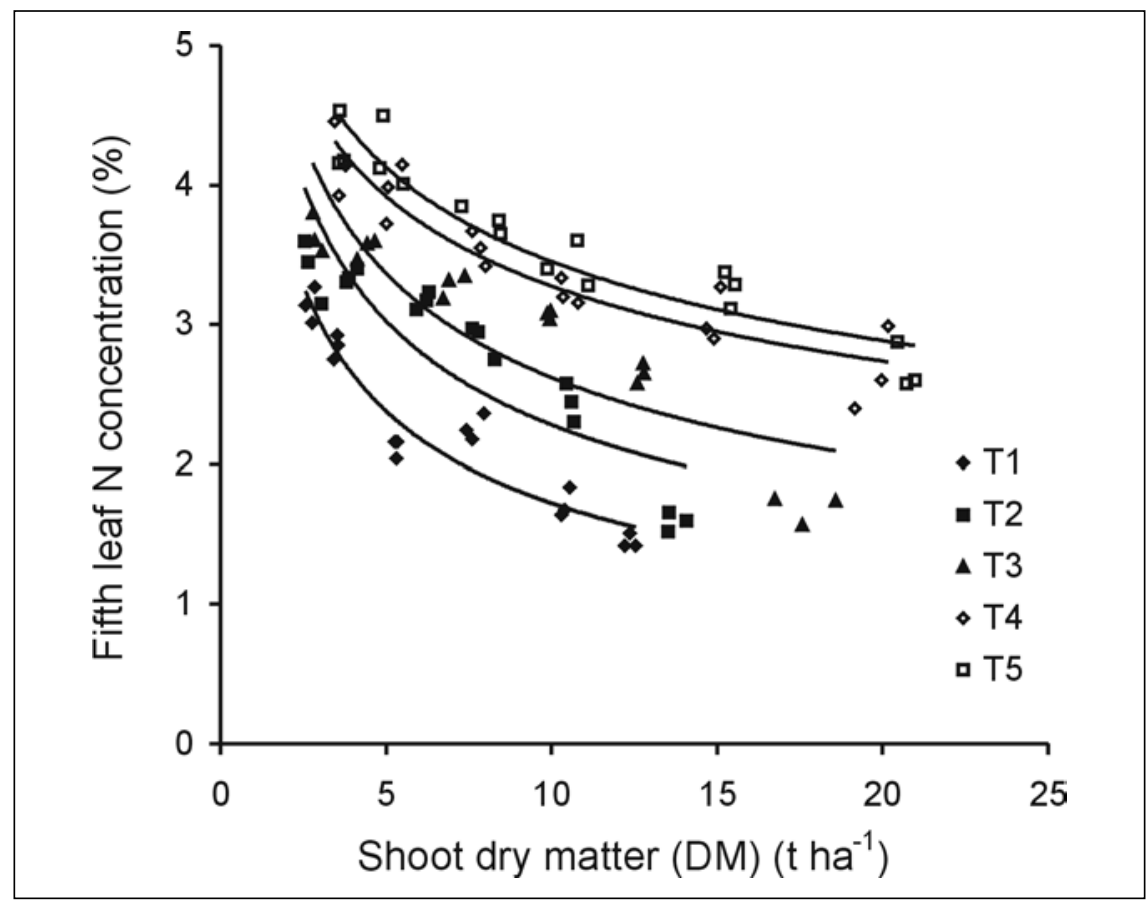

Figure 1. Nitrogen concentration in the fifth leaf during growth of tomato plants under five nutrition levels. (T1: $\% \mathrm{~N}=5.03 \mathrm{DM}^{-0.46}, \mathrm{R}^{2}=0.90 ; \mathrm{T} 2: \% \mathrm{~N}=5.83 \mathrm{DM}^{-0.41}, \mathrm{R}^{2}=0.72 ; \mathrm{T} 3$ : $\% \mathrm{~N}=6.03 \mathrm{DM}^{-0.36}, \mathrm{R}^{2}=0.71 ; \mathrm{T} 4: \% \mathrm{~N}=5.95 \mathrm{DM}^{-0.26}, \mathrm{R}^{2}=0.90 ; \mathrm{T} 5: \% \mathrm{~N}=6.26 \mathrm{DM}^{-0.26}, \mathrm{R}^{2}=$ 0.88). Santa Maria, UFSM, 1999.

$\mathrm{m}^{-2}$, in single rows $(1 \mathrm{~m}$ gully distance and $0.30 \mathrm{~m}$ within-gullies plant distance). Plants were trained according to the high-wire system (FAO, 1990), with one stem per plant. During the experimental period, the greenhouse was ventilated during the day by opening lateral sides when air temperatures were higher than $25^{\circ} \mathrm{C}$.

A nutrient solution containing, in mmol L-1: $\mathrm{KNO}_{3}, 4.0 ; \mathrm{K}_{2} \mathrm{SO}_{4}, 0.9$; $\mathrm{Ca}\left(\mathrm{NO}_{3}\right)_{2}, 3.75 ; \mathrm{KH}_{2} \mathrm{PO}_{4}, 1.5 ; \mathrm{MgSO}_{4}$, 1.0 ; iron chelate $19.10^{-3}$ was used as reference. Remaining microelements were added by a commercial mixture. The T3 treatment was equal to the reference nutrient solution, whereas in treatments T1, T2, T4 and T5 quantities of all nutrients from $\mathrm{T} 3$ were multiplied by $0.25,0.50,1.25$ and 1.50 , respectively. In each treatment, the volume of $1 \mathrm{~L}$ of nutrient solution was supplied to 50 plants once a week by fertigation. Water was delivered daily to plants by drip irrigation, in order to replace volumes lost by transpiration, with a coefficient of drainage of $20 \%$.

Four plants of each treatment were harvested for destructive measurements at $89 ; 96 ; 111 ; 117 ; 131$ and 138 days after sowing. At later harvest, plants had seven trusses and the experiment was ended due to excessively high air temperatures during the day $\left(>32^{\circ} \mathrm{C}\right)$. Guard plants, not used in the experiment, always surrounded selected plants. The fifth leaf, counted from the apex to the bottom of each harvested plant, was detached. Dry matter of leaves, stem (including petioles and peduncles), fruits and detached fifth leaves were determined after drying at $75^{\circ} \mathrm{C}$ for one week. After drying, tissues were fine grounded and total $\mathrm{N}$ concentration was measured in the laboratory, by Kjeldahl method. Values of dry matter accumulation and $\mathrm{N}$ concentration were plotted from samples of the fifth leaf and shoot tissues and curves were fitted using the power model of Salette \& Lemaire (1981) (Eq. 1). A general relationship was fitted between $\mathrm{N}$ concentration in the shoot and in the fifth leaf using data from all harvests.

\section{RESULTS AND DISCUSSION}

The nitrogen concentration in the fifth leaf plotted against dry matter accumulation of shoot organs during growth of plants showed dilution patterns for each one of the five nutrition 


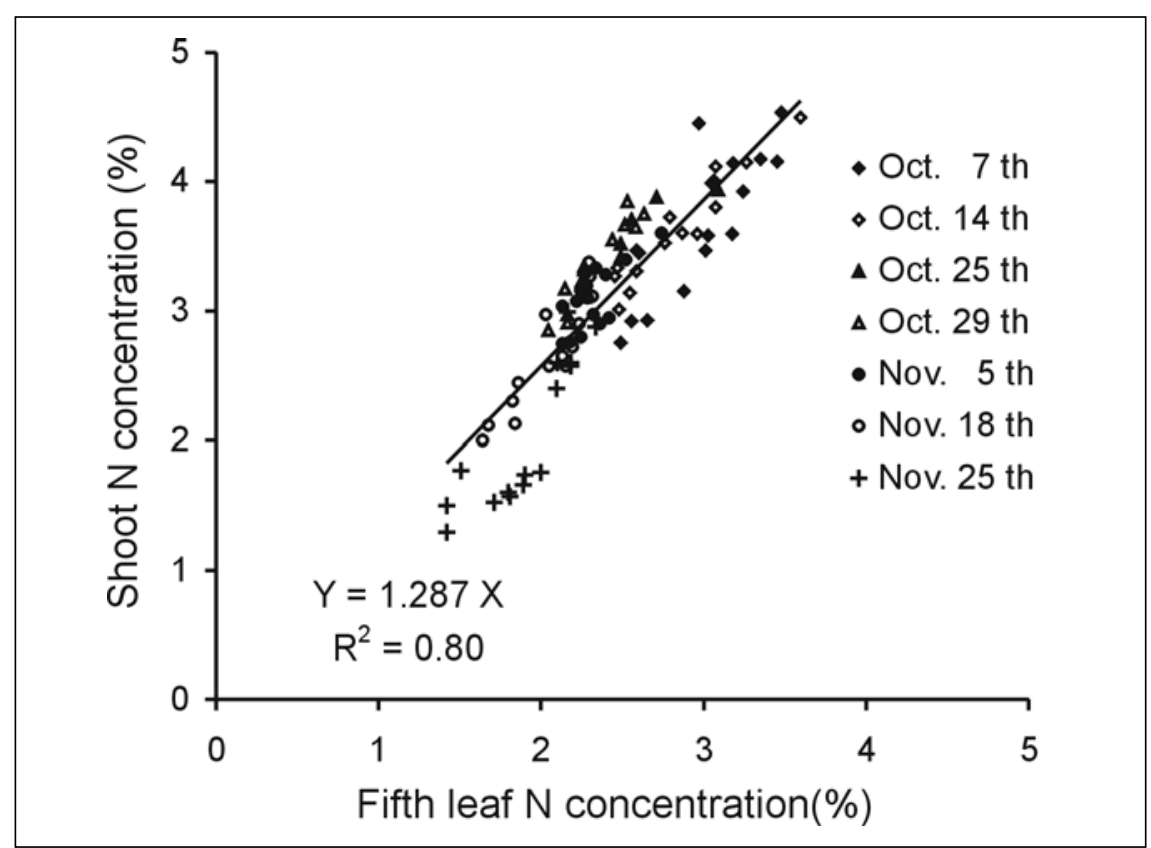

Figure 2. Relationship between $\mathrm{N}$ concentration in the shoot and in the fifht leaf during the growing period of tomato plants supplied with five nutrition levels. Santa Maria, UFSM, 1999.

levels used as treatments (Figure 1). Values of the $a$ coefficient of this model were $5.0 ; 5.8 ; 6.0 ; 5.9$ and 6.3 in $\mathrm{T} 1$, $\mathrm{T} 2, \mathrm{~T} 3, \mathrm{~T} 4$ and $\mathrm{T} 5$, respectively. For the $b$ coefficient of the same model, negative values were $0.46 ; 0.41 ; 0.36$; 0.26 and 0.26 , respectively for the same treatments. When data of $\mathrm{N}$ concentration in the shoot $(\mathrm{Nt})$ and in the fifth leaf $(\mathrm{Nf})$ from all harvests and treatments were pooled together, a linear relationship was found: $\mathrm{Nt}=1.287 \mathrm{Nf}$ $\left(\mathrm{R}^{2}=0.80\right)$ (Figure 2).

The dilution of $\mathrm{N}$ during growth has been previously demonstrated in indeterminate tomato plants grown in NFT, using a nutrient solution with 12 mmolNO3 L ${ }^{-1}$ (Le Bot et al., 1997) and also in substrate grown plants receiving nutrients at weekly intervals (Grave, 1998; Grave et al., 2000; Rattin, 2000). In an experiment using five nutrient levels, Rattin (2000) found a set of five dilution curves, corresponding to each one of the five nutrition levels being compared. As described by Lemaire et al. (1997), the dilution of $\mathrm{N}$ during the growth of the plant could be explained by the simultaneous effect of an increased fraction of dry matter being allocated to storage organs like fruits, and the competition for light among leaves in different positions of the canopy becoming more intense as a consequence of leaf area growth. Thus, $\mathrm{N}$ is remobilized from lower leaves to higher and more illuminated ones, decreasing the $\mathrm{N}$ concentration in the shoot. In the present experiment, a set of dilution curves was observed in the fifth leaf in response to different nutrition levels. This implies absorbed $\mathrm{N}$ was distributed among organs in a similar way, independently of the nutrient level received by plants. If remobilization had occurred, a tendency for a constant $\mathrm{N}$ concentration in the fifth leaf could be expected. This was not the case in the present experiment. Nevertheless, at younger stages of plant development, when competition for assimilates was weak, coefficients $a$ of the power model fitted using data from the five dilution curves of the fifth leaf were on average 1.42 higher than those of dilution curves of the shoot found by Rattin (2000). This can be explained by the fact that in this phase, leaves are in the exponential phase of growth, when the $\mathrm{N}$ concentration is high (Evans, 1993). After maximum growth was attained, $\mathrm{N}$ concentration in leaves decreases (Andriolo, 1995).

Present results showed that dilution of $\mathrm{N}$ during growth also applies for the fifth leaf of tomato plants. It must be kept in mind that in present experiment the fifth leaf at successive harvests was always counted from the apex of the plant. In such a way, its position moves up as the stem grew up. As a consequence, when harvested, these leaves were always at physiological stages before senescence. Thus, physiological causes that could explain $\mathrm{N}$ dilution seem quite different of those pointed out for C3 and C4 annual crops (Greenwood et al., 1990; 1991; Lemaire et al., 1997). In the tomato plant, Heuvelink (1995) suggested a common pool of assimilates, the distribution among organs being regulated by sink strength, independently of the position of each organ on the plant. It may be hypothesised a common pool also for $\mathrm{N}$, the distribution among organs being regulated by prefixed relations of allometry between carbon and nitrogen. In fact, in indeterminately horticultural crops grown in rows like tomato, the canopy structure differs from closed ones, where extinction of light across it begins at early stages of development. Thus, $\mathrm{N}$ dilution during growth of this crop could hardly be attributed to the competition for light.

The relationship showed in Figure 2 was obtained in a range of limiting to non limiting nutrition levels, bellow and above the critical dilution curve determined by Rattin (2000). Thus, it could be considered as a consistent tool to estimate the actual $\mathrm{N}$ concentration (Nt) of tomato crops, from analysis of $\mathrm{N}$ in the fifth leaf sap, from the apex to the bottom of the plant, at any time during the growing period.

\section{ACKNOWLEDGEMENTS}

Márcio Witter is grateful to FAPERGS for a fellowship during this work.

\section{LITERATURE CITED}

ANDRIOLO, J.L. Analyse des flux de $\mathrm{NO}_{3}-\mathrm{H}_{2} \mathrm{O}$ et $\mathrm{CO}_{2}$ au cours de la culture et du nycthémère chez la tomate (Lycopersicon esculentum Mill.) adulte en hors-sol. Montpellier: Université de Montpellier II, 1995, 101 p. (Tese doutorado).

BURNS, I.G. Influence of plant nutrient concentration on growth rate : Use of a nutrient interruption technique to determine critical concentrations of N, P and K in young plants. Plant and Soil, v. 142, p. 221-233, 1992. 
CALOIN, M.; YU, O. Analysis of the time course of change in nitrogen content in Dactylis glomerata L. using a model of plant growth. Annals of Botany, v. 54, p. 69-76, 1984.

CARON, J.; PARENT, L.E. Derivation and assesment of DRIS norms for greenhouse tomatoes. Cannadian Journal of Plant Science, $\mathrm{v}$. 69, p.1027-1035, 1989.

CASTILLA, N.C. Manejo del cultivo intensivo com suelo. In: NUEZ, F. (ed.). El cultivo del tomate. Madrid: Mundi Prensa. p. 189-225, 1995 COLNENNE, C.; MEYNARD, J.M.; REAU, R.; JUSTES, E.; MERRIEN, A. Determination of a critical nitrogen curve for winter oilseed rape. Annals of Botany, v. 81, p. 311-317, 1998.

CTIFL. Centre Technique Interprofessionel des Fruits e des Légumes. Maîtrise de l'irrigation fertilisante. Paris: CTIFL, 1995. 220 p.

EVANS, J.R. Photosynthetic acclimation and nitrogen partitioning within a lucerne canopy. I. Canopy characteristics. Australian Journal of Plant Physiology, v. 20, p. 55-67, 1993.

FAO. Protected cultivation in the mediterranean climate. Food and Agriculture Organization of the United Nations: Rome, 1990. 313 p. (FAO Plant Production and Protection Paper, 90).

GRAVE, R.A. Efeito de diferentes níveis de fertilização nitrogenada sobre o crescimento $e$ acumulação de nitrogênio na planta de tomateiro cultivado em substrato. Santa Maria: UFSM, 1999. 51 p. (Dissertação mestrado).

GREENWOOD, D.J.; LEMAIRE, G.; GOSSE, G.; CRUZ, P.; DRAYCOTT, A.; NEETESON, J.J. Decline in percentage $\mathrm{N}$ of $\mathrm{C} 3$ and $\mathrm{C} 4$ crops with increasing plant mass. Annals of Botany, v. 66, p. 425-436, 1990
GREENWOOD, D.J.; GASTAL, F.; LEMAIRE, G.; DRAYCOTT, A.; MILLARD, P.; NEETESON, J.J. Growth rate and $\% \mathrm{~N}$ of field grown crops: theory and experiments. Annals of Botany, v. 67, p. 181-190, 1991.

GREENWOOD, D.J.; STONE, D.A. Prediction and measurement of the decline in the critical-K, the maximum-K and total cation plant concentrations during growth of field vegetable crops. Annals of Botany, v. 82, p. 871-881, 1998. GRINDLAY, D.J.C.; SYLVESTER-BRADLEY, R.; SCOTT, R.K. Nitrogen uptake of young vegetative plants in relation to green area. Journal Sciences Food Agriculture, v. 63, p. 116, 1993.

HARDWICK, R.C. The nitrogen content of plants and the self-thinning rule of plant ecology: a test of the core-skin hypothesis. Annals of Botany, v. 60, p. 439-446, 1987.

HEUVELINK, E. Dry matter partitioning in a tomato crop: one common assimilate pool? Journal of Experimental Botany, v. 46, p. 1025 1033, 1995.

JUSTES, E.; MARY, B.; MEYNARD, J.M.; MACHET, J.M.; THELIER-HUCHES, L. Determination of a critical nitrogen curve for winter wheat crops. Annals of Botany, v. 74, p. 397-407, 1994.

LE BOT, J.; ANDRIOLO, J.L.; GARY, C.; ADAMOWICS, S.; ROBIN, P. Dynamics of N accumulation and growth of tomato plants in hydroponics: an analysis of vegetative and fruit compartments. In: LEMAIRE, G.; BURNS, I.G. Eds. Diagnostic Procedures for Crop N Management. INRA: Paris, p. 37-51, 1997.
LEMAIRE, G.; DENOIX, A. Relation entre dynamique de croissance et dynamique de prélèvement d'azote pour un peuplement de graminées fourragères. I. Étude de l'effet du millieu. Agronomie, v. 4, p. 423-430, 1987.

LEMAIRE, G.; GASTAL, F.; PLENET, D. Dynamics of $\mathrm{N}$ uptake and $\mathrm{N}$ distribution in plant canopies. Use of crop $\mathrm{N}$ status index in crop modelling. In: LEMAIRE, G.; BURNS, I.G. Eds. Diagnostic Procedures for Crop N Management. INRA: Paris, 1997. p. 15-29.

LOPEZ, C.C.; MAROTTA, J.J.L. Diagnóstico de nutrición y recomendaciones de abonado In: LOPEZ, C.C. (ed.). Fertirrigacion: cultivos horticolas y ornamentales. Madrid: Mundi-Prensa. 1998. p. 175-246.

MARTINEZ, F.C. Manejo del cultivo sin suelo. In: NUEZ, F. (ed.). El cultivo del tomate. Madrid: Mundi Prensa. 1995. p. 227-254.

RAHN, C.R. 1997. Critical N concentrations for modelling the growth of the crops. In: LEMAIRE, G.; BURNS, I.G. Eds. Diagnostic Procedures for Crop N Management. INRA: Paris, 1997. p. 3136.

RATTIN, J.E. Acumulação da massa seca e teores de nitrogênio na planta do tomateiro cultivado sob cinco doses de nutrientes. Santa Maria: UFSM, 2000. 71 p. (Dissertação mestrado).

SALETTE, J.; LEMAIRE, G. Sur la variation de la teneur en azote des graminées fourragères pendant leur croissance: formulation d'une loi de dilution. Compte Rendu de l'Académie des Sciences de Paris, v. 292, p. 875-878, 1981.

ULRICH, A. Physiological bases for assessing the nutritional requirements of plants. Annual Revue Plant Physiology, v. 3, p. 207-228, 1952. 